\title{
Internet User Behavior and Social Media in Learning
}

\author{
Aslam $^{1,2, *}$, Abdul Azis Wahab ${ }^{1}$, Purnama Syae Purrohman ${ }^{2}$, Zulherman $^{2}$, Evy Segarawati Ampry ${ }^{1}$ \\ ${ }^{1}$ Graduate School, ${ }^{2}$ Faculty of Teacher Training and Pedagogy \\ ${ }^{1}$ Universitas Pendidikan Indonesia, ${ }^{2}$ Universitas Muhammadiyah Prof Dr Hamka \\ ${ }^{1}$ Bandung, ${ }^{2}$ Jakarta, Indonesia \\ *ea_aslam@upi.edu
}

\begin{abstract}
This study aims to obtain an overview of the behavior of the internet and social media users in learning. The research was conducted by surveying 99 students, students, and teachers in Muhammadiyah schools in East Jakarta. The survey results show that most respondents use it for pleasure-seeking activities, and the second is learning. Internet security and skills are generally well mastered. Therefore, the behavior in learning using social media and the internet is quite positive in the younger generation's perceptions. Social media and the internet can be a means of learning, sharing, and are not believed to hurt their learning.
\end{abstract}

Keywords-internet, learning, social media, user behavior

\section{INTRODUCTION}

Formal education in schools is currently receiving significant assistance from developments in science and technology (science and technology), especially information and communication technology. Online learning has become the choice of developed countries to increase the APK (gross enrollment rate), namely the level of education of their citizens. As the generation of future leaders, the younger generation has also started to enter the world of work. The research was conducted to discover how the learning behavior of social media users in Indonesia, the research was carried out on teachers and education personnel and education personnel, students, and students at Muhammadiyah charities in Jakarta. They were chosen because they are part of an active population in the education sector in Jakarta, who are used to working and studying using the internet and social media.

Nowadays, social media has become part of an inseparable lifestyle in everyday life. Meylani stated that information and communication technology could improve the quality of education [1]. However, according to Sherlyanita and Rakhmawati, basic knowledge of social media and the internet is necessary to use it for proper learning and entertainment [2]. The use of interactive learning media can increase learning effectiveness, make it easier, fun, and interesting for students, supported by learning data and approaches that are expected theoretically and practically [3]. It can even improve human language learning, especially Balinese [4].

Malaysian society, for example, has more than one social media account, and open it every day several times for communication, social integration, and interaction, sharing entertainment, convenience factors, and the formation of identity [5]. The community needs information literacy to prevent the spread of fake news (hoax) and the role of the government in a procedural manner and the consistent application of the ITE Law [6]. Also, social media is a significant predictor of political participation behavior $[7,8]$. Correa et al. stated that the character of extraversion (energetic and enjoying togetherness) and openness to new experiences were positively correlated with the use of social media. Social media is used as a means of doing business [9-11], because marketing with social media is low cost and easily accessible [11], so that the sales volume of small and medium enterprises can increase by more than $100 \%$ [10].

The research gap from this research is about the focus. While the previous research focused to many aspects without education. This research just focused to education aspect, especially learning process.

\section{THEORETICAL BACKGROUND}

Decision making of individu, group or organization positively or negatively affected by social media at rationality and effectivity [12]. The government body as school use social media to interact with the stakeholders, even there is a challenge related to privacy, security, data management, accesibility, social inclusion, governance, and other information policy issues [13].

Internet user behavior has changed, different from traditional way. The world changed fastly by the development of science and technology. The change at internet user behavior indicated by the change at data trafic volume, application, and user activities. A research implied that many households do file sharing activities, web browsing, multimedia streaming, and online gaming [14].

The smart phone technology now more easy to access. There was a big leap in human life when internet be an important part of life. From Ghose and Han three months research with 2,34 million of mobile data records from $3 \mathrm{G}$ user of smartphones, indicated that social networking has strong positive effect to mobile internet user behavior [15]. The research conducted at 2018, and now the data will be increasing. 
Social media is a site for their user interactivity. Nowaday the use of social media very massive. The parent should be warned about the characteristics of social media like facebook, whatsapps, twitter, youtube etcetra. Not all the social media give the healthy environment for children and adolescent. Some accident could be happen as cyberbullying, "facebook depression", sexting, and exposed to unappropriate contents [16].

However, according to Soliha, which strengthens Caplan's research, social anxiety is positively correlated with pathological internet use (PIU) [17]. Thus, in broad terms, internet and social media content can be used for entertainment and education or learning. The literature above has not described how the behavior of social media users in Indonesia, especially among students. This study seeks to understand how the behavior of using social media and the internet among educated people in Indonesia. Both from the digital native generation, as well as the previous generation. Hidayat said Indonesia occupies the sixth position of the world's most significant internet users [18]. According to the Indonesian Internet Service Providers Association (APJII), the number of internet users in Indonesia grew by 10.12 percent. There were 171 million users on the calculation of April 14, 2019 [19]. Supratman's research on digital native states that they need an understanding of the substance of information obtained from the internet, has critical reasoning to manage to interpret and to evaluate social media critically [20]. Different figures are quoted from the website www.wearesocial.com, We Are Social, which states that there are 132.7 internet users in Indonesia.

The learning environment within internet will growing faster and faster. IPTS (Institute for Prospective Technological Studies), an European based institution, research findings cited Redecker, indicate that Learning 2.0 gives rise to technological innovation in Education and Training by:

- increasing the accessibility and availability of learning content;

- providing new formats for knowledge dissemination, acquisition and management;

- allowing for the production of dynamic learning resources and environments of high;

- quality and interoperability;

- embedding learning in more engaging and activating multimedia environments;

- supporting individualised learning processes by allowing learner preferences to be;

- accounted for;

- equipping learners and teachers with versatile tools for knowledge exchange; and

- collaboration, which overcome the limitations of faceto-face instruction [21].

\section{METHODS}

\section{A. Time and Place of Research}

The research was carried out at schools and campuses belonging to the Muhamadiyah organization located in East Jakarta. The research is planned to be carried out on February 28,2019 , to July 30,2019 . The research population target is 150 teachers, lecturers, students, and students at this Muhammadiyah charity.

\section{B. Data Collection}

The research method used is a survey method; researchers used a questionnaire distributed to teachers, students, and students in educational institutions belonging to the Muhammadiyah organization, targeted at 150 people. Thus the descriptive quantitative research method is applied in this research.

The questionnaire used is based on previous research that discusses Livingstone's social media behavior, quoted from Supratman [20] about media literacy. Before submitting, the questionnaire was discussed with an information technology expert from the UHAMKA Faculty of Engineering, named Sg. Moreover, I discussed in a Focus Group Discussion with fellow lecturers at UHAMKA. Questions are submitted in two ways, namely utilizing paper questionnaires and questionnaires that are accessed using the online form.

\section{RESULTS AND DISCUSSION}

This study obtained 99 participants who volunteered to be involved in this study. $14 \%$ were 19 years old, $12.1 \%$ are 20 years old, $12.1 \%$ are 21 years old, and $10 \%$ are 19 years old. The rest is divided between the age range of 18 years to 40 years as attached. By gender, the respondents consisted of $83 \%$ women and $16 \%$ men. Meanwhile, according to the level of education, most respondents are already in their fourth year of higher education $(54.5 \%)$, and the second majority are first and second-year students (34\%). The reasons for using the internet show in figure 1.

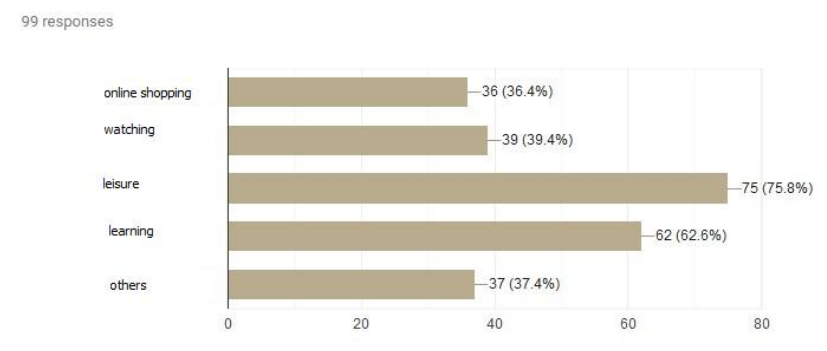

Fig. 1. Reasons for using the internet.

The result of the research states that educated people generally use the internet for entertainment, rather than for studying. However, the difference between entertainment and learning is quite small, and this shows that interest in learning 
is quite significant, although interest in recreation is higher among students in Jakarta. This is in line with Supratman's research, which describes that the use of social media by digital natives is to obtain information, virtual communication, support education, online shopping, cultural adoption, and exploration of talent interests [20].
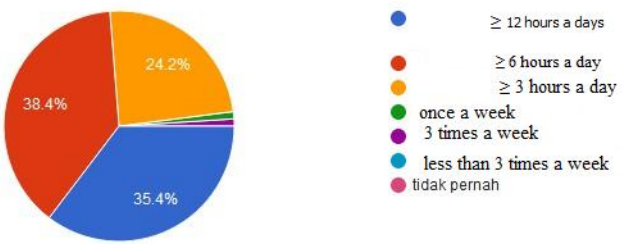

Fig. 2. Frequency of using the internet.

This study also confirms that the number of years students use the internet the data show in figure 2, including social media, is quite high. $38.4 \%$ of them logged into cyberspace for 6 hours or more, while a smaller margin $(35.4 \%)$ had the frequency of using the internet for 12 hours or more, either consecutively or continuously. They interacted with the internet via social media on average for 30 minutes, as much as $36.4 \%$, in second place who interacted for more than 3 hours! This shows that they already have a second life, apart from their daily real life. Currently, overseas students can still connect with their families using social media applications, making it low cost and effective.

Unlike in the past, the $1990 \mathrm{~s}$ relied a lot on telecommunication shops, which had to queue and had limited communication due to high costs. This study is different from Kemp's research, which measures that daily internet use is confirmed 6,5 hours per a day in a year [22]. Research data shows that the lowest is three times a week (see in figure 3 ). Globally, according to wearesocial.com data. In 2018, the country with the most extended average duration of social media was the Philippines, Brazil second, and Indonesia, and Thailand in third place. The concept of internet dependence (internet addiction), according to Starcevic and Aboujaoude, needs to be reexamined because the internet is a medium for addictive behavior such as gameplay, sexual activity, or online gambling [23].

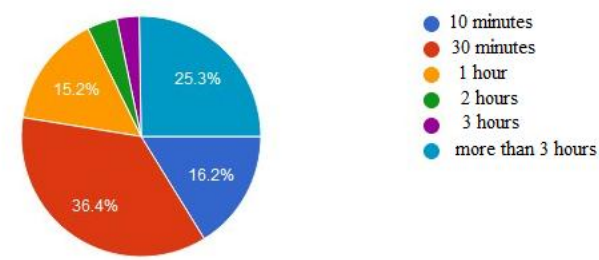

Fig. 3. The average frequency of interacting in the internet network.
From figure 4, the most dominant internet activity carried out is reading news, updating status, uploading photos, and viewing profiles. From these data, it can be seen that the patterns in absorbing information have shifted from conventional mass media to online media. Likewise, the pattern of friendship and social relations has also expanded, not just face to face. Interactions that use media, such as the internet and social media, are different from face to face. Because the facial expression is also not visible. According to Dwi Nur A.'s research, the online community creates new interaction patterns but still has conventional interaction patterns [24]. It raises conformity in a community where the pressure is not subject to the members, but these members accept it without feeling forced.

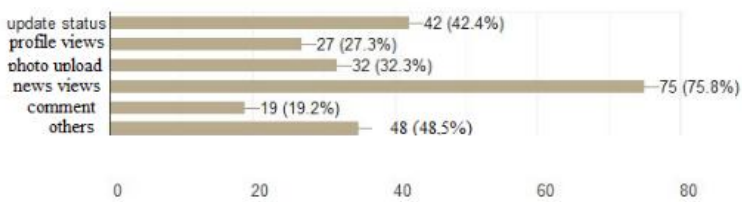

Fig. 4. Types of social media activities

The majority of respondents understand safe internet skills. Generally, respondents are skilled at positively surfing the internet and other necessary skills, which are now assisted by various easy-to-master applications. They also generally have the strong skills required to be well connected on The respondents can be categorized as the generation who are used to interacting with the internet. On average, the master general Internet skills, such as blocking messages or friends, changing profiles, uncomplicated editing of videos and images, searching for information, looking for learning resources, using search engines, functions in games, and chatting, send text or multimedia messages, and search for references from journals.

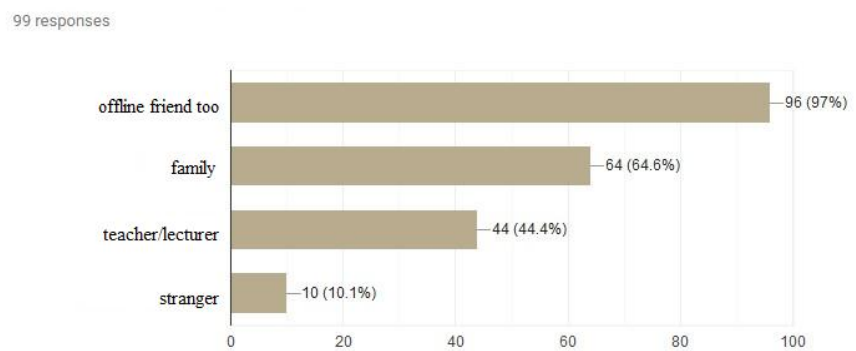

Fig. 5. Kinds of friends on social media.

The Indonesian nation is known as a friendly nation and is open to mingling with various nations. Various news stories highlight the existence of crimes committed through internet channels and social media. The results in figure 5 of the questionnaire show that most friendships on social media from respondents are based on friendships in the real world. Whether friends from school, college, fellow alumni (96\%), apart from 
that, family, lecturers/teachers, and strangers. Unknown people usually come from friends or have certain similarities in hobbies, music, and others. Setyaningsih's research states that there are three significant risks of communicating in cyberspace, if you are not careful, namely sexual exploitation, cyberbullying, and misuse of personal data [25]. Such openness must be added with care, as many factors make room for evil for the user. Cyberbullying can continue in the real world.

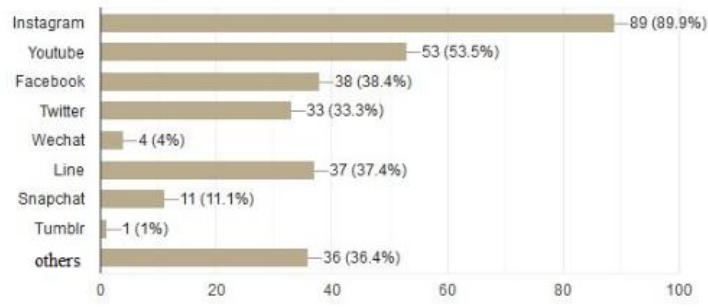

Fig. 6. Types of active used social media.

From the figure 6, the most owned and active social media is Instagram. Instagram features photos, videos, and short writing features. It has limitations but makes communication more effective and efficient to get the message across and receive it. Instagram can be a reference for finding data and facts for millennials. If, in the early days of the internet, people searched for information by opening search engines, now that has been abandoned. Instagram is a place to ask questions to find specific products or services and how to do something.

In second place is YouTube. Currently, it is quite popular in Indonesia because this social media channel is bringing up many conventional artists and "new model" artists. Being a new way to generate income that is quite democratic, anyone can become an artist. According to data from wearesocial.com, In January 2018, the most actively used platform in the world is Facebook. The second place is YouTube, followed by WhatsApp, FB Messenger, WeChat, QQ, and Instagram.
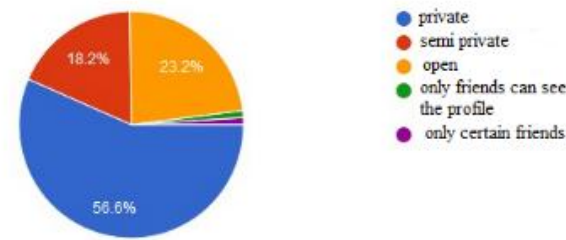

Fig. 7. Profile settings.

Figure 7 show the profile setting on social media is significant. Because with this profile, our data will be exposed by other people. It can be used for evil or good. Therefore, it is essential to be careful in this matter. More than half of the respondents set their profile on private mode. So it is not open to the public. However, $23.2 \%$ make it open to the public and $18.2 \%$ half private.
The majority of respondents agreed that social media nowadays makes it easier to socialize. With social media, distance is no longer an obstacle. It can even be used to facilitate communication at work and studying and other things that were previously impossible. Social media also makes it easier to share knowledge. However, this convenience also has drawbacks. Due to its location in the cell phone storage, the data is vulnerable to lose due to various factors. When asked whether social media makes it easy to improve self-efficacy in knowledge, attitudes, and understanding, only $30.3 \%$ were very confident about this statement. This proves that certain things require real-life improvement in the form of face-to-face and structured guidance.

The majority of respondents believe that social media makes it easy to learn from various sources. Because with social media, the transfer of documents, pictures, videos, and so on can be done quickly. For students in lectures, social media and internet literacy is quite good, and this is evident that many students use social media to get ready to recognize the material that will be delivered by the lecturer before lectures. For today's lecturers, better literacy is needed than students, especially information and communication technology literacy. The Government of the Republic of Indonesia has a social media account to open a service imbalance report called LAPOR!, However, reports submitted to the government are edited in advance by social media administrator [26].

Social media is used for self-actualization (see figure 8), sometimes even for the show of something "wow." Something that makes other people jealous and wants to copy it. However, currently, the "bullying" behavior on social media in Indonesia is quite violent. Every so often, we hear the news of unpleasant actions and complaints to the authorities because of social media. The younger generation in this survey did not really like sharing their feelings on social media. Because they are prone to be bullied by other parties, which are not even recognized. The emergence of risks in social media, according to Setyaningsih's research, is influenced by internal factors (gender, naivety, and internet literacy skills) and external (anonymity, conflict with parents, and lack of parental supervision) [25].

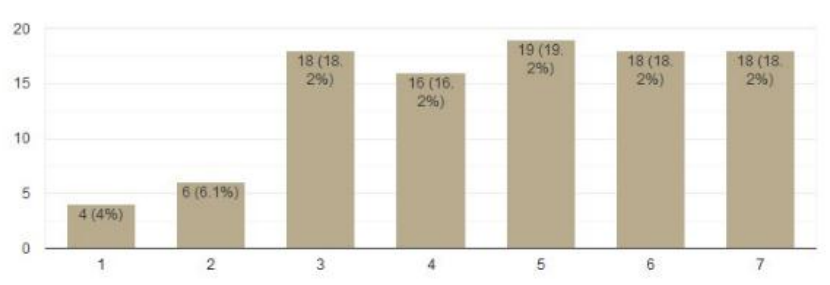

Fig. 8. Social media as a tool for sharing opinions and feelings. 


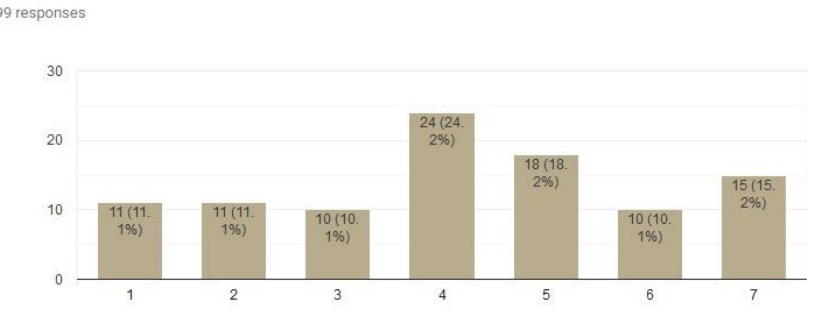

Fig. 9. The impact of frequent use of social media on learning.

When it comes to learning, there are doubts about the function of social media. This shows that in the hearts of respondents, they admit that too much social media will impact their learning abilities (show in figure 9). As for writing skills, there are beliefs and uncertainties about the impact of social media. It shows how social media use differs among respondents.

Whether social media discourages respondents, the answers are relatively even-generally, doubt about the statement. Likewise, the statement that social media results in low scores. In the figure $10,28 \%$ were in doubt, and this is the majority. Whether social media discourages respondents, the answers are relatively even-generally, doubt about the statement. Likewise, the statement that social media results in low scores. $28 \%$ were in doubt, and this is the majority.

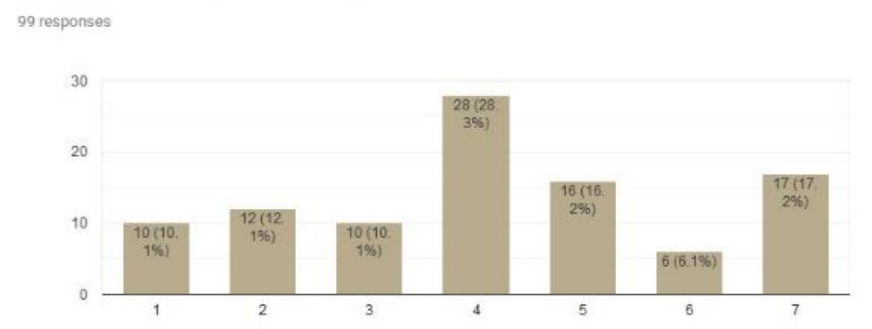

Fig. 10. Social media effect for learning result.

Social media in the perceptions of the younger generation today is quite good; they doubt the researchers 'statement that social media can have an impact on low scores, and have an impact on low learning motivation as well as on students' mental health.

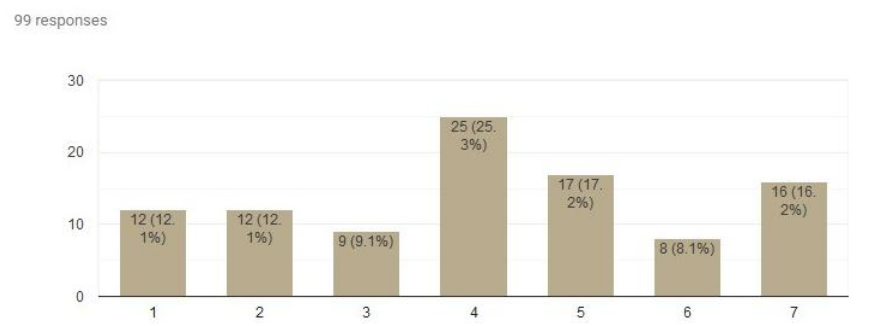

Fig. 11. Social media and learning motivation.

The final questionnaire question was asked about the impact of social media on respondents' health in general. Both physical and psychological health. The proportion who agree is
$49.6 \%$ with a gradation between agree entirely to agree. The middle figure is $16.2 \%$, and those who strongly disagree that social media hurt student health is $15.2 \%$. This data confirms the research that social media, as presented in nationalgeographic.co.id [27]. Especially in mental health. According to the article, summarizing various studies, the use of social media leads to long-term unhappiness and isolation. Kecmanovic says the tips for not being disturbed by mental health are to limit the time and place to use social media; schedule a "detox" period, i.e., time without social media /internet; pay attention to what you do and how you feel (when using social media/internet); use social media mindfully: why am I using this? cut; and, not a substitute for real life.

\section{CONCLUSION AND RECOMMENDATION}

The results of this study concluded that social media and the internet had become an inseparable part of the younger generation's lifestyle. They make it a part of a healthy life, which is different from the previous generation. The results of this study concluded that social media and the internet had become an inseparable part of the younger generation's lifestyle. They make it a part of a healthy life, which is different from the previous generation. They have a positive attitude towards social media, even though various studies prove otherwise.

\section{REFERENCES}

[1] Melyani, "Pengembangan pendidikan berbasis teknologi informasi dan komunikasi (TIK) untuk meningkatkan mutu pendidikan," In: Konferensi Nasional Ilmu Sosial \& Teknologi (KniST), p. 152-8, 2017.

[2] A. Sherlyanita and N. Rakhmawati, "Pengaruh dan pola penggunaan internet serta media sosial pada siswa SMPN 52 Surabaya," J Inf Syst Eng Bus Intell, vol. 2, no. 1, 2016

[3] N. Yuniati, B.E. Purnama and G.K. Nugroho, "Pembuatan Media Pembelajaran Interaktif Ilmu Pengetahuan Alam Pada Sekolah Dasar Negeri Kroyo 1 Sragen," J Speed Sentra Penelit Eng dan Edukasi, vol. 3, no. 4, pp. 25-9, 2011.

[4] I.G.A.A.S.S. Dewi, I.G.W. Sudhata and A.I.W.I.Y. Sukmana, "Pengembangan multimedia pembelajaran interaktif berorientasi pendidikan karakter mata pelajaran Bahasa Bali," J Educ Technol, vol. 3, no. 3, pp. 190-5, 2019.

[5] S.E. Mustafa and A. Hamzah, "Media Baharu yang Baharu: trend penggunaan jaringan sosial dalam kalangan pengguna di Malaysia," Malaysian J Media Stud., vol. 13, no. 2, pp. 93-110, 2011.

[6] R. Pakpahan, "Analisis fenomena hoax di berbagai media sosial dan cara menanggulangi hoax," In: Konferensi Nasional Ilmu Sosial \& Teknologi (KNiST), p. 479-84, 2017.

[7] T. Correa, A.W. Hinsley and H.G. Zùniga de, "Who interact on the web?" the intersection of users' personality and social media use," Comput Human Behav., vol. 29, pp. 247-53, 2010.

[8] H.G. Zùňiga de, "Social media use for news and individuals' social capital, civic engagement and political participation," J Comput Commun., vol. 17, 2012.

[9] I.A.I. Asriani and G.S. Darma, "Peran Media Sosial Online dan Komunitas terhadap Keputusan Nasabah Bank," J Manaj dan Bisnis, vol. 10 , no. 2,2013

[10] S. Priambada, "Manfaat penggunaan media sosial pada usaha kecil menengah (UKM)," In: Seminar Nasional Sistem Informasi Indonesia. Jakarta: SESINDO; 2015. 
[11] T. Siswanto, "Optimalisasi sosial media sebagai media pemasaran usaha kecil menengah," J Liq., vol. 2, no. 1, pp. 80-6, 2013.

[12] D.J. Power and G.P. Wren, "Impact of Social Media and Web 2.0 on Decision-Making," J Decis Syst., vol. 20, no. 3, pp. 249-61, 2013.

[13] J.C. Bertot, P.T. Jaeger and D. Hansen, "The impact of polices on government social media usage: Issues, challenges, and recommendations," Gov Inf Q [Internet]. 29:30-40, 2012. Available from: www.elsevier.com/locate/govinf

[14] M. Kihl, P. Ödling, C. Lagerstedt and A. Aurelius, Traffic analysis and characterization of Internet user behavior. Lund; 2010. Report No.: 2010 International Congress on Ultra Modern Telecommunications and Control Systems and Workshops (ICUMT).

[15] A. Ghose and S-P. Han, "An Empirical Analysis of User Content Generation and Usage Behavior on the Mobile Internet," Oper Inf Decis Pap Whart Fac Res Univ Pennsylvania Sch., vol. 9, pp. 1-47, 2011.

[16] G.S. O'Keeffe and K. Clark-Pearson, Clinical Report-The Impact of Social Media on Children, Adolescents, and Families [Internet]. 2011. Available from: www.pediatrics.org/cgi/doi/10.1542/peds.2011-0054

[17] S.F. Soliha, "Tingkat ketergantungan pengguna media sosial dan kecemasan sosia," J Ilmu Komun., vol. 4, no. 1, pp. 1-10, 2015.

[18] W H. Pengguna internet Indonesia nomor enam dunia [Internet]. 2016. Available from: kominfo.go.id/content/detail/4286/pengguna-internetindonesia-nomor-enam-dunia/0/sorotan_media pada 11 Desember 2019

[19] Pratomo Y. APJII: Jumlah pengguna internet di Indonesia tembus 171 $\begin{array}{lll}\text { juta jiwa. Available } & \text { from: }\end{array}$ https://tekno.kompas.com/read/2019/05/16/03260037/apjii-jumlahpengguna-internet-di-indonesia-tembus-171-juta-jiwa

[20] L.P. Supratman, "Penggunaan Media Sosial oleh Digital Native," J ILMU Komun., vol. 15, no. 1, pp. 47-60, 2015.

[21] C. Redecker, K.A. Mutka and Y. Punie, Learning 2.0 - The Impact of Social Media on Learning in Europe, Policy Brief [Internet]. Seville; 2010. Available from: http://www.jrc.ec.europa.eu/

[22] S. Kemp, Digital trends 2019: Every single stat you need to know about the internet. The Next Web. 2019.

[23] V. Starcevic and E. Aboujaoude, "Internet Addiction: reappraisal of an increasingly inadequate concept," CNS Spectr., vol. 22, no. 01, pp. 7 $13,2016$.

[24] A.A. Dwi Nur, Pola mutual interaksi pada komunitas online: Jogjadivgram dan dampaknya terhadap kohesivitas komunitas. Universitas Gadjah Mada, 2016.

[25] R. Setyaningsih, "Bahaya berkomunikasi di media sosial." Proyeksi, vol. 9, no. 2, pp. 91-103, 2014

[26] A.L. Pakuningjati, Konferensi Nasional Ilmu Sosial \& Teknologi (KNiST). Universitas Gadjah Mada, 2015.

[27] J. Kecmanovic, Lindungi Kesehatan Mental dari Bahaya Media Sosial, Berikut Tipsnya [Internet]. National Geografic Indonesia. 2016. Available from: https://nationalgeographic.grid.id/read/131775652/lindungi-kesehatanmental-dari-bahaya-media-sosial-berikut-tipsnya?page $=2$ 